Vol. 2 No. 1 Maret 2022, e-ISSN : 2797-8842 | p-ISSN : 2797-9431

\title{
PENGGUNAAN MODEL PROBLEM BASED LEARNING UNTUK MENINGKATKAN HASIL BELAJAR IPS MATERI LETAK DAN LUAS INDONESIA
}

\author{
CHIKMAH \\ MTs Negeri 2 Kota Semarang \\ e-mail: chikmahnashir@gmail.com
}

\begin{abstract}
ABSTRAK
Penelitian ini bertujuan untuk meningkatkan hasil belajar siswa pada materi letak dan luas Indonesia dengan menggunakan model problem based learning. Penelitian yang digunakan adalah penelitian tindakan kelas. Dengan yang diteliti penerapan penggunakan model pembelajaran problem based learning dalam peningkatan keaktifan dan hasil belajar siswa. Hasil penelitian menunjukkan adanya peningkatan hasil belajar siswa dari pra siklus, siklus I hingga siklus II yaitu pada pra siklus diketahui hasil belajar kompetensi pengetahuan dari jumlah siswa 32 hanya ada $7(21,88 \%)$ siswa yang mendapatkan nilai $\geq 73(\mathrm{KKM})$ dengan nilai ratarata kelas 55,88; pada siklus I sudah ada peningkatan menjadi $21(65,63 \%)$ peserta didik yang mencapai KKM dengan nilai rata-rata kelas 74,84 dan pada siklus II sudah ada $29(90,63 \%)$ peserta didik yang mendapatkan nilai mencapai KKM dengan nilai rata-rata kelas 82,38. Peningkatan hasil belajar ini juga terdapat pada hasil belajar keterampilan atau kinerja dimana pada pra siklus hanya ada $9(28,13 \%)$ siswa yang mencapai KKM $(73)$ dengan nilai rata-rata kelas 59,06; pada siklus I sudah ada $19(59,37 \%)$ peserta didik yang mendapatkan nilai mencapai KKM dengan nilai rata-rata kelas 75,59 dan siklus II sudah mencapai $32(100 \%)$ peserta didik yang mendapatkan nilai mencapai KKM dengan rata-rata kelas 80,06. Peningkatan hasil belajar siswa juga tampak pada kompetensi sikap, walaupun seleuruh siswa sudah mencapai KKM sejak pra siklus, peningkatan pada nilai sikpa yaitu pada pra siklus yang mendapatkan nilai sikap A ada $3(9,38 \%)$, siswa yang mendapatkan nilai sikap B ada 29 (90,63\%), pada siklus I menjadi $13(40,63 \%)$ peserta didik yang mendapatkan kategori A atau amat baik dan ada $19(59,37 \%)$ peserta didik yang mendapatkan kategori B atau Baik, pada siklus II ada 18 (56,25\%) peserta didik yang mendapatkan kategori A atau amat baik dan ada $14(43,75 \%)$ peserta didik yang mendapatkan kategori B atau Baik dan tidak ada siswa yang mendapatkan nilai C (cukup) ataupun D (kurang).
\end{abstract}

Kata Kunci : Problem Based Learning, Metode Pembelajaran, Pembelajaran IPS

\section{ABSTRACT}

This study aims to improve student learning outcomes on the material location and area of Indonesia by using a problem based learning model. The research used is classroom action research. With the researched application of the use of problem based learning learning model in increasing student activity and learning outcomes. The results showed that there was an increase in student learning outcomes from pre-cycle, cycle I to cycle II, namely in the precycle it was known that the knowledge competency learning outcomes from the number of students were 32 , there were only $7(21.88 \%)$ students who scored $>73(\mathrm{KKM})$ with a score of class average 55.88; in the first cycle there was an increase to $21(65.63 \%)$ students who achieved the KKM with an average grade of 74.84 and in the second cycle there were 29 $(90.63 \%)$ students who scored reaching the KKM with a grade class average 82.38. This increase in learning outcomes is also found in skills or performance learning outcomes where in the pre-cycle there were only $9(28.13 \%)$ students who achieved the KKM (73) with a class average of 59.06; in the first cycle there were 19 (59.37\%) students who scored reaching the KKM with an average grade of 75.59 and the second cycle had reached 32 (100\%) students who scored reaching the KKM with a class average 80.06. The increase in student learning outcomes also appears in the attitude competence, although all students have reached the KKM since the pre-cycle, the increase in the sikpa score, namely in the pre-cycle who got the attitude 
A score was 3 (9.38\%), students who got the attitude B score were 29 (90.63\%), in the first cycle there were $13(40.63 \%)$ students who got category A or very good and there were 19 $(59.37 \%)$ students who got category B or good, in the second cycle there were $18(56.25 \%)$ students got category A or very good and there were 14 (43.75\%) students who got category B or good and no students got C (enough) or D (less).

Keywords: Problem Based Learning, Learning Methods, Social Studies Learning

\section{PENDAHULUAN}

Pendidikan merupakan suatu upaya dalam mempersiapkan sumber daya manusia (human resource) yang memiliki keterampilan dan keahlian sesuai tuntutan pembangunan bangsa. Pendidikan memegang peranan penting dalam mencerdaskan kehidupan bangsa, oleh karena itu setiap individu yang terlibat dalam pendidikan dituntut berperan serta secara maksimal guna meningkatkan mutu pendidikan tersebut.

Sekolah atau madrasah merupakan salah lembaga pendidikan yang dipercaya oleh pemerintah dan masyarakat Indonesia dalam mempersiapkan generasi penerus bangsa dalam memajukan bangsanya di kancah persaingan tekhnologi serba canggih saat ini melalui dunia pendidikan. Sekolah juga merupakan sebuah tempat terjadinya kegiatan belajar mengajar dalam rangka meningkatkan sumberdaya manusia agar dapat menjadi manusia-manusia bangsa Indonesia yang mampu bersaing dengan bangsa-bangsa lain. Di lingkungan sekolah ini juga terdapat interaksi antara guru dan siswa dengan tujuan posistif yaitu sebagai transfer of knowledge and value.

Menurut Djamarah dan Aswan (2006: 82), kegiatan belajar mengajar yang melahirkan unsur-unsur manusiawi adalah sebagai suatu proses dalam rangka mencapai tujuan pengajaran. Seorang guru harus selalu berusaha mengatur lingkungan belajar agar bergairah bagi peserta didik. Berbekal berbagai teori dan pengalaman yang telah dimilikinya menggunakannya untuk mempersiapkan program pengajaran dengan baik dan sistematis.

Kegiatan proses belajar mengajar di dalam kelas, guru merupakan komponen yang sangat penting, sebab keberhasilan pelaksanaan proses pendidikan sangat tergantung pada guru sebagai ujung tombak, yang berhubungan langsung dengan siswa sebagai subjek dan objek belajar. Kegiatan guru dalam membimbing siswa sangat diharapkan karena berdampak pada keberhasilan siswa. Selain itu, keberhasilan pembelajaran tidak hanya dilihat dari hasil belajar yang dicapai oleh siswa, akan tetapi juga dari segi proses belajarnya. Hasil belajar pada dasarnya merupakan akibat dari suatu proses belajar, sehingga optimalnya hasil belajar siswa bergantung pula pada kualitas kegiatan poses belajar mengajar. Demikian pula, dalam pembelajaran Ilmu Pengetahuan Sosial (IPS) yang diharapkan di sekolah pelaksanaannya mengikuti prinsip belajar aktif. Sebagai landasan penguraikan apa yang dimaksud dengan belajar menurut Ngalim Purwanto (2007:84) belajar adalah setiap perubahan yang relatif menetap dalam tingkah laku yang terjadi sebagai suatu hasil dari latihan atau pengalaman.

Peran guru dalam pelaksanaan kegiatan belajar mengajar sangat penting untuk membantu siswa agar aktif terlibat dalam proses pembelajaran sangat diharapkan. Guru harus memiliki kemampuan profesional yakni menciptakan kualitas pembelajaran untuk mendorong siswa berpartisipasi aktif. Dalam hal ini Rice dan Bishoprick berpendapat dalam bukunya Ibrahim (2004:5) bahwa guru profesional adalah guru yang mengelola dirinya dalam melaksanakan tugas-tugasnya seharihari. Profesionalisasi guru dipandang sebagai sebuah proses yang bergerak dari ketidaktahuan (ignorance) menjadi tahu, dari ketidakmatangan (immaturity) menjadi matang, dan diarahkan orang lain (other-directedness) menjadi mengarahkan diri sendiri. Dengan kata lain guru profesional adalah orang yang memiliki kemampuan dan keahlian khusus dalam bindang keguruan sehingga ia mampu melakukan tugas dan fungsinya sebagai guru dengan kemampuan maksimal (Kunandar, 2007:46-47).

Tugas guru tidak hanya mengajar untuk menyampaikan materi pelajaran saja, akan tetapi juga suatu proses untuk mengubah perilaku siswa sesuai dengan tujuan yang diharapkan. Guru dituntut mencari tahu terus-menerus bagaimana peserta didik itu belajar. Maka, apabila 
ada kegagalan peserta didik, guru mencari penyebabnya dan mencari jalan keluar bersama peserta didik bukan mendiamkannya atau bahkan menyalahkannya akan tetapi mencari solusi agar peserta didik dapat belajar dengan baik dan berhasil dalam pembelajarannya. Sikap yang harus senantiasa dipupuk adalah kesedian untuk mengenal diri dan kehendak untuk memurnikan keguruannya.

Pelaksanaan kegiatan proses belajar mengajar terdapat kegiatan membimbing siswa agar berkembang, melatih keterampilan baik keterampilan intelektual maupun keterampilan motorik, sebagai pengkaitan pengetahuan baru pada struktur kognitif baru yang sudah dimiliki siswa. Pengkaitan-pengkaitan ini akan membentuk struktur kognitif baru yang lebih mantap, yang dapat dipandang sebagai hasil belajar.

Hasil observasi awal hasil belajar IPS pada materi letak dan luas wilayah Indoensia di kelas VII B, dimana kelas VII B di MTS Negeri 2 Kota Semarang merupakan kelas unggulan masih banyak siswa yang mendapatkan nilai di bawah Kriteria Ketuntasan Minimal (KKM) dari jumlah siswa 32 hanya ada $7(21,88 \%)$ yang mencapai KKM (73), sedangkan yang lainya yaitu $25(78,12 \%)$ masih mendapatkan nilai di bawah KKM pada ranah pengetahuan atau kognitif, untuk hasil belajar kinerja siswa juga masih banyak siswa yang mendapatkan nilai di bawah KKM, dengan nilai rata-rata pengetahuan 5,51 dimana siswa diminta untuk membuat peta wilayah Indonesia, namun hal itu kurang berpengaruh pada penegtahuan siswa yangmana dapat dilihat dari hasil belajar pengetahuan siswa di atas dengan masih banyaknya siswa yang mendapatkan nilai di bawah KKM. Kurang berpengaruhnya terhadap kemampuan pengetahuan siswa, karena banyak siswa yang tidak selesai dalam membuat peta wilayah Indonesia pada waktu yang telah ditentukan dan sudah diberi kelonggaran 2 minggu, namun tetap saja masih banyak siswa yang belum menyelesaikan tugasnya untuk membuat peta wilayah Indonesia. Dari jumlah siswa 32 hanya ada $9(28,13 \%)$ siswa yang mendapatkan nilai kinerja di atas KKM sedangkan yang lainya $23(71,87 \%)$ masih mendapatkan nilai di bwah KKM, dengan nilai ratarata 5,55 sedangkan nilai sikap berdasarkan pengamatan penulis yang juga merupakan guru IPS di kelas VII B MTs Negeri 2 Kota Semarang walaupun tidak ada yang sampai mendapatkan predikat "C" namun banyak siswa yang mendapatkan predikat "B", sedangkan yang mendapatkan predikat " $A$ " hanya ada 3 saja.

Masih banyaknya siswa yang mendapatkan nilai di bawah KKM hal ini membuat penulis untuk melakukan perbaikan pembelajaran dengan bertany dan berdialog dengan kepala sekolah, kurikulum dan teman sejawat, dan pada akhirnya penulis memutuskan untuk menggunakan model pembelajaran Problem Based Learning (PBL) atau juga sering disebut juga pembelajaran berbasis masalah. Dengan penggunaan model pembelajaran PBL ini diharapkan dapat meningkatkan motivasi dan hasil belajar siswa baik pada ranah pengetahuan, kinerja atau keterampilan maupun pada sikap ketika mengikuti proses belajar mengajar mata pelajaran IPS materi letak dan luas wilayah Indonesia semester 1 di kelas VII B MTs Negeri 2 Kota Semarang tahun pelajaran 2018/2019.

Problem Based Learning (PBL) adalah suatu model pembelajaran yang melibatkan siswa untuk memecahkan masalah melalui tahap-tahap metode ilmiah sehingga siswa dapat mempelajari pengetahuan yang berhubungan dengan masalah tersebut dan sekaligus memiliki ketrampilan untuk memecahkan masalah (Kamdi, 2007: 77). PBL atau pembelajaran berbasis masalah sebagai suatu model pembelajaran yang menggunakan masalah dunia nyata sebagai suatu konteks bagi siswa untuk belajar tentang cara berpikir kritis dan keterampilan pemecahan masalah, serta untuk memperoleh pengetahuan dan konsep yang esensial dari materi pelajaran. Dengan model pembelajaran problema based learning inilah, diharapkan hasil belajar akan meningkat.

Dan penelitian tindakan kelas ini bertujuan agar hasil belajar siswa kelas VIIB pada materi letak dan luas Indonesia mata pelajaran IPS semester 1 dengan menggunakan model problema based learning bisa meningkat. Adapun rumusan permasalahan yang ada dalam penelitian adalah bagaimanakah peningkatan hasil belajar siswa kelas VII B pada materi letak 
dan luas Indonesia mata pelajaran IPS semester 1 dengan menggunakan model pembelajaran Problem Based Learning MTs Negeri 2 Kota Semarang tahun pelajaran 2018/2019.

\section{METODE PENELITIAN}

Penelitian ini menggunakan pendekatan kuantitatif yaitu penelitian yang memuat datadata numerial dan mendeskripsikan data-data mengenai hasil belajar pada siswa MTs Negeri 2 Kota Semarang. Penelitian ini dilakukan mulai tanggal 1 Agustus - 30 September 2018. Metode Yang digunakan dalam penelitian adalah metode problem based learning. Ciri-ciri PBL menurut Ibrahim dan Nur (dalam Nurhadi, dkk., 2004: 57) adalah sebagai berikut.

a. Pengajuan pertanyaan atau masalah

PBL bukan hanya mengorganisasikan prinsip-prinsip atau keterampilan akademik tertentu, melainkan mengorganisasikan pmbelajaran di sekitar pertanyaan dan masalah yang kedua-keduanya secara sosial penting dan secara pribadi bermakna untuk siswa. Mereka mengajukan situai kehidupan nyata yang autentik, menghindari jawaban sederhana, dan memungkinkan adanya berbagai macam solusi untuk situasi itu.

b. Berfokus pada keterkaitan antar disiplin

Meskipun PBL mungkin berpusat padamata pelajaran tertentu (IPA, Matematika, Ilmuilmu Sosial), masalah yang akan diselidiki telah dipilih benar-benar nyata agar dalam pemecahannya siswa meninjau masalah itu dari banyak mata pelajaran.

c. Penyelidikan autentik

PBL mengharuskan siswa melakukan penyelidikan autentik untuk mencari penyelesaian terhadap masalah nyata. Mereka harus menganalisis dan mendefinisikan masalah, mengembangkan hipotesis dan membuat ramalan, mengumpulkan dan menganalisis informasi, melakukan eksperimen (jika diperlukan), membuat inferensi, dan merumuskan kesimpulan.

d. Menghasilkan produk/karya dan memamerkannya

PBL menuntut siswa untuk menghasilkan produk tertentu dalam karya nyata atau artefak dan peragaan yang menjelaskan atau mewakili bentuk penyelesaian masalah yang mereka temukan. Produk itu dapat berupa transkrip debat, laporan, model fisik, video atau program komputer.

PBL biasanya terdiri dari lima tahapan, yaitu mengorientasi siswa kepada masalah, mengorganisasi siswa untuk belajar, membimbing penyelidikan individual/kelompok, mengembangkan dan menyajikan hasil karya siswa, dan menganalisis dan mengevaluasi proses pemecahan masalah.

Prosedur yang digunakan dalam perancangan siklus dalam penelitian tindakan menurut Kemmis dan Taggar dalam (Arikunto, 2006) meliputi tahap-tahap sebagai berikut :

1. Perencanaan ( planning)

2. Tindakan (acting)

3. Observasi (observing)

4. Refleksi (reflecting)

Selanjutnya siklus itu akan berulang terus. Banyaknya siklus yang dilakukan tergantung dari peningkatan nilai hasil belajar. Proses siklus akan berhenti pada saat siswa sudah mengalami peningkatan nilai hasil belajar yaitu siswa mencapai ketuntasan minimal dalam proses nilai hasil belajarnya. Adapun lokasi penelitian di MTs Negeri 2 Kota Semarang. Subyek penelitiannya yaitu kelas VIIB yang berjumlah 32 siswa yang terdiri dari 14 siswa perempuan dan 18 siswa laki-laki.

\section{HASIL DAN PEMBAHASAN}

\section{A. Deskripsi Data}

\section{Deskripsi Data Pra Siklus}

Hasil obsevasi pra siklus diambil dari hasil ulangan harian siswa pada mata pelajaran IPS materi letak dan luas Indonesia hasil nilai harian ini merupakan nilai pengetahuan siswa di kelas 
VII B MTs Negeri 2 Kota Semarang, dinama pada proses pembelajarannya guru belum menggunakan model pembelajaran Probelm Based Learning, hasil belajar siswa pada nilai pengetahuan yaitu dari jumlah siswa 32 hanya ada 7 (21,88\%) yang mencapai KKM (73), sedangkan yang lainya yaitu $25(78,12 \%)$ masih mendapatkan nilai di bawah KKM pada ranah pengetahuan atau kognitif dengan nilai rata-rata 55, 88. Dengan nilai tertinggi 89 dan nilai terendah 21

Hasil observasi pra siklus pada nilai keterampilan, dimana pada pra siklus ini guru dalam melaksanakan pembelajaran IPS materi letak dan luas Indonesia belum menggunakan model pembelajaran Probelm Based Learning, hasil belajar siswa pada nilai keterampilan atau kinerja pra siklus ini yaitu dari jumlah siswa 32 hanya ada $9(28,13 \%)$ siswa yang mendapatkan nilai kinerja di atas KKM sedangkan yang lainya 23 (71,87\%) masih mendapatkan nilai di bwah KKM pada ranah ketrampilan dengan nilai rata-rata 58,90. Nilai tertinggi 89, dan nilai terendah 21

Pencapaian hasil belajar siswa kelas VII B MTs Negeri 2 Kota Semarang pada mata pelajaran IPS materi letak dan luas Indonesia tahap pra siklus dapat digambarkan pada digram berikut:

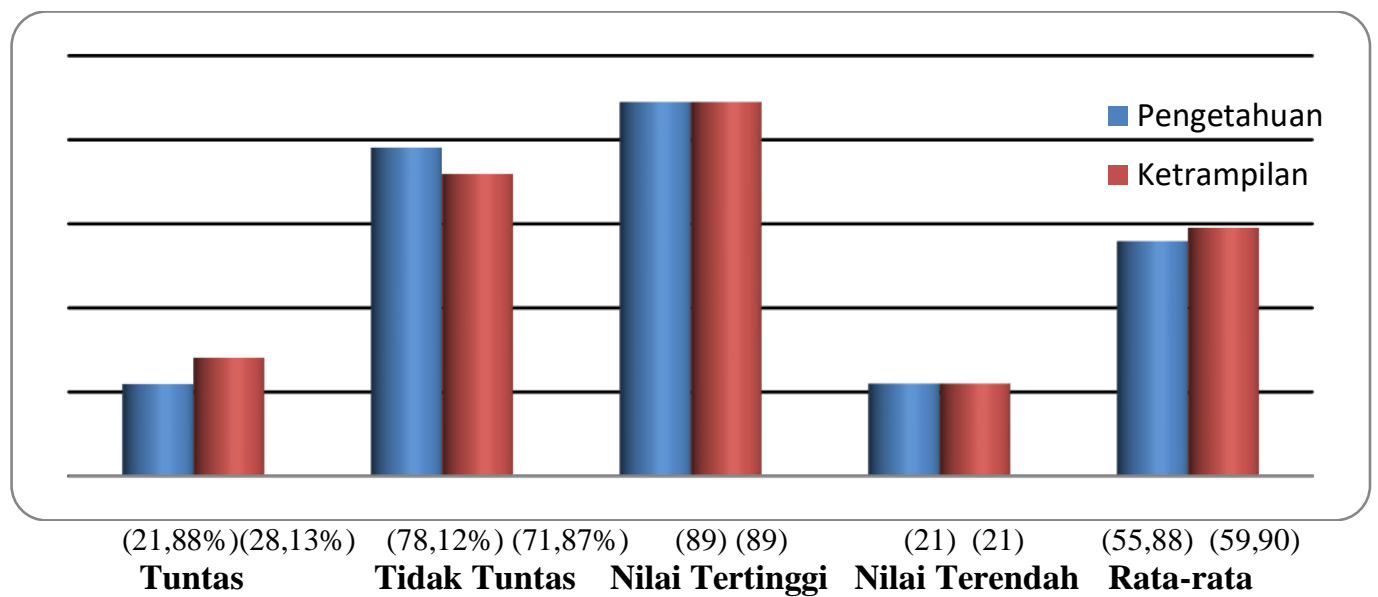

Gambar 1. Diagram Nilai Pengtahuan dan Keterampilan Pra Siklus

\section{Deskripsi Data Siklus I}

Hasil ketuntasan pada nilai pengetahuan peserta didik pada pembelajaran letak dan luas Indonesia dengan menggunakan model pembelajaran Probelm Based Learning di kelas VII B MTs Negeri 2 Kota Semarang pada siklus 1 terdapat $21(65,63 \%)$ peserta didik yang mendapatkan nilai mencapai KKM $(\geq 73)$ dari 32 peserta didik, sedangkan yang belum mencapai KKM $(<73)$ ada $11(34,37 \%)$ peserta didik. Nilai rata-rata kelas pada siklus ini mencapai 74,84. Nilai tertinggi mencapai 94 dan nilai terendah siswa mencapai 39.

Hasil ketuntasan pada nilai keterampilan atau kinerja peserta didik pada pembelajaran letak dan luas Indonesia dengan menggunakan model pembelajaran Probelm Based Learning di kelas VII B MTs Negeri 2 Kota Semarang pada siklus 1 terdapat $19(59,37 \%)$ peserta didik yang mendapatkan nilai mencapai KKM $(\geq 73)$ dari 32 peserta didik, sedangkan yang belum mencapai KKM (<73) ada $13(40,63 \%)$ peserta didik. Nilai rata-rata kelas pada kompetensi kinerja atau keterampilan siklus 1 mencapai 75,59. Nilai tertinggi mencapai 89 dan nilai terendah siswa mencapai 67.

Pencapaian hasil belajar siswa kelas VII B MTs Negeri 2 Kota Semarang pada mata pelajaran IPS materi letak dan luas Indonesia tahap pra siklus dapat digambarkan pada digram berikut: 


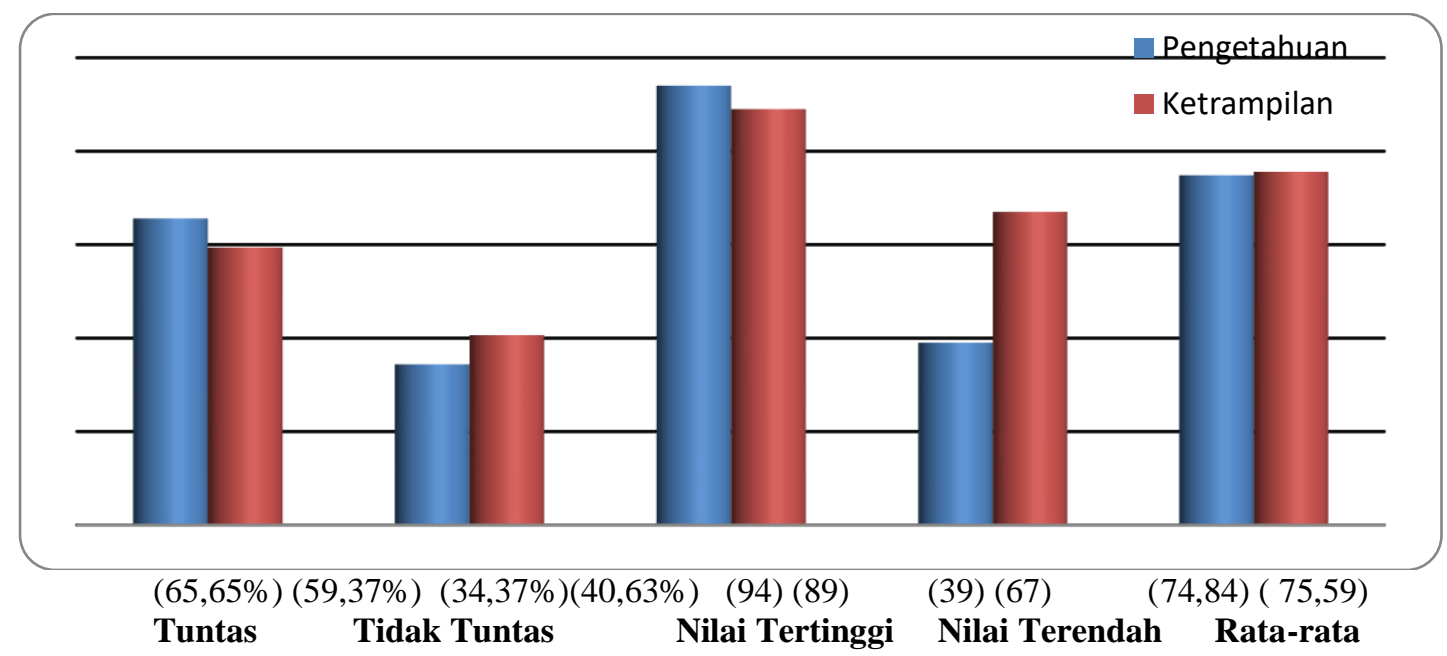

\section{Gambar 2. Diagram Nilai Pengetahuan dan Keterampilan Tahap Siklus I}

\section{Deskripsi Data Siklus II}

Hasil ketuntasan pada nilai pengetahuan peserta didik pada pembelajaran letak dan luas Indonesia dengan menggunakan model pembelajaran Probelm Based Learning di kelas VII B MTs Negeri 2 Kota Semarang pada siklus II sudah ada 29 (90,63\%) peserta didik yang mendapatkan nilai mencapai KKM $(\geq 73)$ dari 32 peserta didik, sedangkan yang belum mencapai KKM $(<73)$ hanya ada $3(9,37 \%)$ peserta didik. Nilai rata-rata kelas pada siklus ini mencapai 82,38. Nilai tertinggi mencapai 95 dan nilai terendah siswa mencapai 60.

Hasil ketuntasan pada nilai keterampilan atau kinerja peserta didik pada pembelajaran letak dan luas Indonesia dengan menggunakan model pembelajaran Probelm Based Learning di kelas VII B MTs Negeri 2 Kota Semarang pada siklus II sudah mencapai 32 (100\%) peserta didik yang mendapatkan nilai mencapai KKM ( $\geq 73)$ dari 32 peserta didik, dan tidak ada peserta didik yang mendapatkan nilai dibawah KKM. Nilai rata-rata kelas pada kompetensi kinerja atau keterampilan siklus II mencapai 80,06. Nilai tertinggi mencapai 89 dan nilai terendah siswa mencapai 78.

Nilai ketuntasan peserta didik dalam mengikuti pembelajaran letak dan luas Indonesia dengan menggunakan model pembelajaran Probelm Based Learning di kelas VII B MTs Negeri 2 Kota Semarang siklus II untuk kompetensi pengetahuan dan keterampilan dapat digambarkan dalam diagram sebagai berikut:

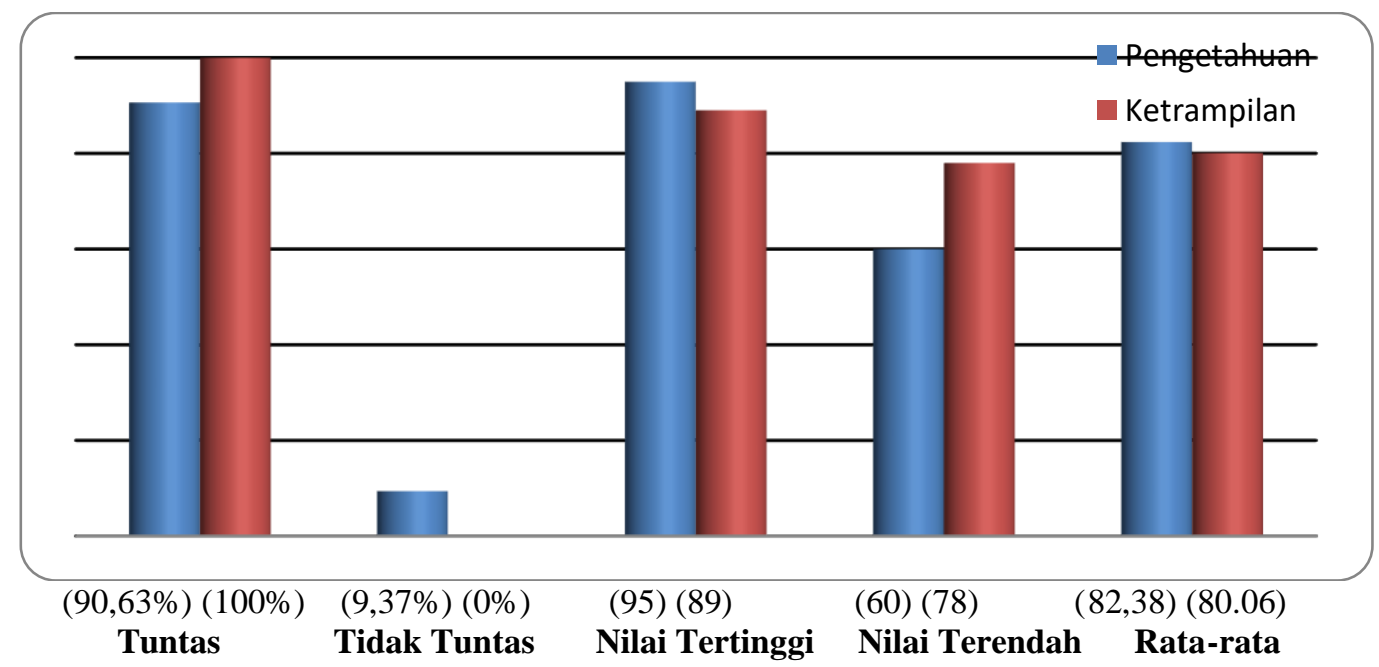

Gambar 3. Diagram Nilai Pengetahuan dan Keterampilan Tahap Siklus II 
Peningkatan hasil belajar pengetahuan dan keketrampilan atau kinerja siswa kelas VII B MTs Negeri 2 Kota Semarang pada meteri letak dan luas Indonesia dengan menggunakan model pembelajaran Probelm Based Learning ini mulai dari pra siklus, siklus I sampai siklus II dapat digambarakan dalam table berikut:

Gambar 1. Tabel Nilai Pengetahuan Tahap Pra Siklus, Siklus I, dan Siklus II

\begin{tabular}{|c|c|c|c|}
\hline Keterangan & Pra Siklus & Siklus I & Siklus II \\
\hline Nilai Terendah & 21 & 39 & 60 \\
\hline Nilai Tertinggi & 89 & 94 & 95 \\
\hline Tuntas & $21,88 \%$ & $65,65 \%$ & $90,63 \%$ \\
\hline Tidak Tuntas & $78,12 \%$ & $34,37 \%$ & $9,37 \%$ \\
\hline Rata-rata & 55,88 & 74,84 & 82,38 \\
\hline
\end{tabular}

Gambar 2. Tabel Nilai Ketrampilan Tahap Pra Siklus, Siklus I, dan Siklus II

\begin{tabular}{|c|c|c|c|}
\hline Keterangan & Pra Siklus & Siklus I & Siklus II \\
\hline Nilai Terendah & 21 & 67 & 78 \\
\hline Nilai Tertinggi & 89 & 89 & 89 \\
\hline Tuntas & $28,13 \%$ & $59,37 \%$ & $100 \%$ \\
\hline Tidak Tuntas & $71,87 \%$ & $40,63 \%$ & $0 \%$ \\
\hline Rata-rata & 59,90 & 75,59 & 80,06 \\
\hline
\end{tabular}

\section{B. Pembahasan}

Berdasarkan ulasan hasil penelitian dari pra siklus, siklus I dan siklus II di atas, proses pembelajaran IPS materi letak dan luas Indonesia dengan menggunakan model pembelajaran Probelm Based Learning pada siklus I dan II kelas VII B MTs Negeri 2 Kota Semarang dapat dikahui bahwa hasil belajar siswa selalu meningkat, baik pada nilai pengetahaun, nilai keterampilan atau kinerja maupaun pada nilai sikap, dimana nilai sikap ini diambil selama siswa mengikuti kegiatan belajar mengajar IPS materi letak dan luas Indonesia dengan menggunakan model pembelajaran Probelm Based Learning.

Peningkatan hasil belajar kelas VII B MTs Negeri 2 Kota Semarang pada pembelajaran IPS materi letak dan luas Indonesia dengan menggunakan model pembelajaran Probelm Based Learning dapat dilihat secara bertahap dari pra siklus, siklus I dan siklus II.

Berdasarkan hasil analisis data pra siklus dapat diketahui bahwa hasil pra siklus siswa kelas VII MTs Negeri 2 Kota Semarang pada materi letak dan luas Indonesia masih banyak siwa yang belum mencapai ketuntasan yang diharapkan. Pada hasil belajar kompetensi pengetahuan dapat diketahui bahwa dari jumlah siswa 32 hanya ada $7(21,88 \%)$ siswa yang mendapatkan nilai $\geq 73(\mathrm{KKM})$, sedangkan yang lainya yaitu $25(78,12 \%)$ siswa mendapatkan nilai di bawah KKM, nilai kinerja siswa berupa tugas individu membuat gambar peta Indoensia dari jumlah siswa 32 hanya ada $9(28,13 \%)$ siswa yang mencapai KKM, sedangkan yang lainya $23(71,87 \%)$ siswa masih mendapatkan nilai dibawah KKM, hal ini disebabkan karena masih banyak sekali siswa yang tidak menyelesaikan tugasnya, walaupun guru sudah sering menegurnyadi samping itu hasil abservasi awal pada ulangan harian menunjukkan masih banyak siswa yang mendapatkan nilai di bawah KKM terutama pada kompetensi pengetahuan dan keterampilan.

Peneliti yang merupakan guru IPS di kelas VII B MTs Negeri 2 Kota Semarang melakukan usaha-usaha untuk meningkatkan hasil belajar IPS pada materi letak dan luas Indonesia dengan menghadirkan inovasi model pembelajaran. Innovasi model pembelajaran yang penulis tawarkan yaitu model pembelajaran Probelm Based Learning. Problem Based Learning (PBL) adalah suatu model pembelajaran yang melibatkan siswa untuk memecahkan masalah melalui tahap-tahap metode ilmiah sehingga siswa dapat mempelajari pengetahuan yang berhubungan dengan masalah tersebut dan sekaligus memiliki ketrampilan untuk memecahkan masalah (Kamdi, 2007: 77). PBL atau pembelajaran berbasis masalah sebagai 
suatu model pembelajaran yang menggunakan masalah dunia nyata sebagai suatu konteks bagi siswa untuk belajar tentang cara berpikir kritis dan keterampilan pemecahan masalah, serta untuk memperoleh pengetahuan dan konsep yang esensial dari materi pelajaran. Dengan model pembelajaran Probelm Based Learning diharapkan hasil belajar siswa mata pelajaran IPS materi letak dan luas Indonesia dapat dapat meningkat dan mencapai KKM.

Pada siklus I, pembelajaran IPS materi letak dan luas Indonesia dengan menggunakan model pembelajaran Probelm Based Learning. Berdasarkan dari keterangan pencapaian hasil belajar siswa baik pada kompetensi pengetahuan, kinerja atau keterampilan dan sikap, pada siklus I sudah ada peningkatan. Peningkatan hasil belajar pada siklus I ini yaitu pada kompetensi penegtahuan sudah ada $21(65,63 \%)$ peserta didik yang mendapatkan nilai mencapai KKM ( $\geq 73)$ dari 32 peserta didik, sedangkan yang belum mencapai KKM $(<73)$ ada $11(34,37 \%)$ peserta didik. Nilai rata-rata kelas pada siklus ini mencapai 74,84. Nilai tertinggi mencapai 94 dan nilai terendah siswa mencapai 39. Hasil ketuntasan pada nilai keterampilan atau kinerja peserta didik pada pembelajaran letak dan luas Indonesia dengan menggunakan model pembelajaran Probelm Based Learning di kelas VII B MTs Negeri 2 Kota Semarang pada siklus 1 terdapat $19(59,37 \%)$ peserta didik yang mendapatkan nilai mencapai KKM $(\geq 73)$ dari 32 peserta didik, sedangkan yang belum mencapai KKM $(<73)$ ada $13(40,63 \%)$ peserta didik. Nilai rata-rata kelas pada kompetensi kinerja atau keterampilan siklus 1 mencapai 75,59. Nilai tertinggi mencapai 89 dan nilai terendah siswa mencapai 67. amat baik, ada 19 (59,37\%).

Peningkatan yang telah dicapai pada siklus I sebagaimana keterangan di atas, apabila dikaitkan dengan target penelitian ini belum memenuhi target pada penelitian ini. Sebagaimana sudah diketahui bahwa pada siklus 1 hasil belajar kompetensi pengetahuan ada $21(65,63 \%)$ peserta didik yang mendapatkan nilai mencapai KKM $(\geq 73)$ dari 32 peserta didik, sedangkan target prosentase dalam penelitian ini yaitu $80 \%$, jadi untuk prosentase ketuntasan siswa pada nilai pengetahun belum memenuhi target dan perlu tindak lanjut ke siklus berikutnya. Nilai rata-rata kelas pada kompetensi pengetahuan siklus 1 mencapai 74,84, dan target pencapain nilai rata-rata pengetahuan penelitian ini yaitu 73, jadi pada siklus 1 ini untuk nilai rata-rata kelas pada nilai pengetahuan sudah tercapai. Hasil belajar pada kompetensi keterampilan ada $19(59,37 \%)$ peserta didik yang mendapatkan nilai mencapai KKM ( $\geq 73)$ dari 32 peserta didik, sedangkan target prosentase dalam penelitian ini yaitu $80 \%$, jadi untuk prosentase ketuntasan siswa pada nilai keterampilan atau kinerja belum memenuhi target dan perlu tindak lanjut ke siklus berikutnya. Nilai rata-rata kelas pada kompetensi keterampilan atau kinerja siklus 1 mencapai 75,59 dan target pencapain nilai rata-rata keterampilan penelitian ini yaitu 73, jadi pada siklus 1 ini untuk nilai rata-rata kelas pada nilai keterampilan sudah tercapai.

Berdasarkan pada hasil refleksi siklus I terhadap berbagai kegiatan siswa, ditemukan berbagai kelemahan dan kendala yang perlu diatasi agar pembelajaran dapat mencapai hasil yang lebih baik lagi. Rencana perbaikan tersebut sebagai berikut; dalam proses pembelajaran siklus I sudah tampak adanya peningkatan baik dari nilai pengetahuan, keterampilan atau kinerja dan sikap. Namaun hasil belajar prosentase ketuntasan pada kompetensi pengetahuan dan keterampilan belum memenuhi target penelitin ini. Untuk mengatasi belum tercapainya target penenltian ini pada prosentase ketuntasan siswa baik pada kompetensi pengetahuan maupun keterampilan atau kinerja, maka peneliti perlu mengevaluasi dan meningkatkan lagi hal-hal yang berkaiatan dengan proses belajar mengajar IPS materi letak dan luas Indonesia dengan menggunakan model pembelajaran Probelm Based Learning di kelas VII B MTs Negeri 2 Kota Semarang pada siklus 1, sehingga pada siklus berikutnya dapat meningkat sesuai dengan target yang diharapkan. Berdasarkan kurang maksimalnya guru dalam memotivasi siswa, maka guru perlu meningkatkan lagi dalam memotivasi siswa pada siklus berikutnya. Untuk lebih jelasnya prosedur pembelajaran IPS materi letak dan luas Indonesia dengan menggunakan model pembelajaran Probelm Based Learning, guru lebih aktif dan menyeluruh dalam mendapingi ssiwa dalam memecahkan masalah yang diberikan pada guru.

Rencana perbaikan yang telah disusun tersebut dilaksanakan pada siklus II, dengan menggunakan model pembelajaran Probelm Based Learning sehingga hasil belajar siswa kelas 
VII B pada materi letak dan luas Indonesia mata pelajaran IPS dapat meningkat dan mencapai sesuai target penelitian ini.

Pembelajaran siklus II merupakan tindak lanjut dari hasil refleksi siklus I, dimana pada siklus I belum tercapainya target penelitian prosesntasi hasil belajar pada kompetensi pengetahuan dan keterampilan. Sebagai bahan pembeda antara siklus I dan siklus II, pada siklus II ini peneliti memfokuskan pada letak geografis wilayah Indonesia sedangkan pada siklus I difokuskan pada letak astronomis wilayah Indonesia, hal ini juga dapat digunakan sebagai kevalid-an keefektifan penggunaan model pembelajaran Problem Based Learning dalam pembelajaran IPS materi letak dan luas wilayah Indonesia.

Guru memperbaiki proses belajar mengajar IPS materi letak dan luas Indonesia dengan menggunakan model pembelajaran Probelm Based Learning sesuai hasil refleksi siklus I di atas, sehingga pada siklus II ini hasil pembelajaran letak dan luas Indonesia siswa mengalami beberapa peningkatan yaitu hasil ketuntasan pada nilai pengetahuan peserta didik pada pembelajaran letak dan luas Indonesia dengan menggunakan model pembelajaran Probelm Based Learning di kelas VII B MTs Negeri 2 Kota Semarang pada siklus II sudah ada 29 $(90,63 \%)$ peserta didik yang mendapatkan nilai mencapai KKM $(\geq 73)$ dari 32 peserta didik, sedangkan yang belum mencapai KKM $(<73)$ hanya ada $3(9,37 \%)$ peserta didik. Nilai ratarata kelas pada siklus ini mencapai 82,38. Nilai tertinggi mencapai 95 dan nilai terendah siswa mencapai 60. Hasil ketuntasan pada nilai keterampilan atau kinerja peserta didik pada pembelajaran letak dan luas Indonesia dengan menggunakan model pembelajaran Probelm Based Learning di kelas VII B MTs Negeri 2 Kota Semarang pada siklus II sudah mencapai 32 $(100 \%)$ peserta didik yang mendapatkan nilai mencapai KKM ( $\geq 73)$, maka pada kompetensi keterampilan ini tidak ada peserta didik yang mendapatkan nilai di bawah KKM. Nilai rata-rata kelas pada kompetensi kinerja atau keterampilan siklus II mencapai 80,06. Nilai tertinggi mencapai 89 dan nilai terendah siswa mencapai 78.

Peningkatan yang telah dicapai pada siklus II sebagaimana keterangan di atas, apabila dikaitkan dengan target penelitian ini dapat diketahui bahwa pencapaian hasil belajar pengetahuan sudah ada $29(90,63 \%)$ peserta didik yang mendapatkan nilai mencapai KKM ( $\geq 73$ ) dari 32 peserta didik, dan target prosentase dalam penelitian ini yaitu $80 \%$, dengan kata lain prosentase ketuntasan siswa pada nilai pengetahun sudah memenuhi target penelitian ini dan tidak perlu tindak lanjut ke siklus berikutnya. Nilai rata-rata kelas pada kompetensi pengetahuan siklus II Judah mencapai 82,38 juga sudah memenuhi target penelitian ini yaitu 73. Hasil belajar keterampilan atau kinerja pada siklus II ini sudah mencapai 32 (100\%) peserta didik yang mendapatkan nilai mencapai KKM ( $\geq 73)$, dan target prosentase dalam penelitian ini yaitu $80 \%$, jadi untuk prosentase ketuntasan siswa pada nilai keterampilan atau kinerja sudah memenuhi target dan tidak perlu tindak lanjut ke siklus berikutnya. Nilai rata-rata kelas pada kompetensi keterampilan atau kinerja siklus II juga sudah mencapai 80,06 dan target pencapain nilai rata-rata keterampilan penelitian ini yaitu 73 , jadi pada siklus II ini untuk nilai rata-rata kelas pada nilai keterampilan sudah tercapai. Nilai tertinggi mencapai 89 dan nilai terendah siswa mencapai 78.

Dan berdasarkan gambar tabel 2.1 diketahui terdapat peningkatan hasil belajar pengetahuan siswa kelas VII B MTs Negeri 2 Kota Semarang pada meteri letak dan luas Indonesia dengan menggunakan model pembelajaran Probelm Based Learning ini mulai dari pra siklus, siklus I sampai siklus II dengan ketuntasan sebagai berikut pra siklus $(21,88 \%)$ meningkat menjadi $(65,65 \%)$ kemudian meningkat lagi ketuntasannya menjadi $(90,63 \%)$.

Dan berdasarkan gambar tabel 2.2 diketahui terdapat peningkatan hasil belajar ketrampilan siswa kelas VII B MTs Negeri 2 Kota Semarang pada meteri letak dan luas Indonesia dengan menggunakan model pembelajaran Probelm Based Learning ini mulai dari pra siklus, siklus I sampai siklus II dengan ketuntasan sebagai berikut pra siklus $(28,13 \%)$ meningkat menjadi $(59,37 \%)$ kemudian meningkat lagi ketuntasannya menjadi (100\%).

Peningkatan hasil belajar siswa kelas VIIB MTs Negeri 2 Kota Semarang pada materi letak dan luas Indonesia dengan menggunakan model problem based learning ini sejalan dengan 
penelitian tindakan kelas yang terlebih dahulu dilakukan pada tahun 2016 oleh Sakinah dengan judul Penerapan Model Problem Based Learning untuk Meningkatkan Hasil Belajar Siswa Pada Pembelajaran Fiqih di Kelas VIII MTs Babun Najah Kota Banda Aceh.

\section{KESIMPULAN}

Berdasarkan hasil penelitian dan pembahasan pada bab-bab sebelumnya, maka hasil penelitian dapat disimpulkan berikut: Pelaksanaan pembelajaran IPS materi letak dan luas Indonesia dengan menggunakan model pembelajaran Probelm Based Learning di kelas VII B MTs Negeri 2 Kota Semarang semester 1 tahun pelajaran 2018/2019 telah dapat meningkatkan hasil belajar siswa, yang dilaksanakan pada dua siklus yaitu siklus I dan II.

Peningkatan hasil belajar siswa kelas VII MTs Negeri 2 Kota Semarang dengan menggunakan model pembelajaran Probelm Based Learning materi letak dan luas Indonesia semester genap tahun pelajaran 2018/2019 tampak pada adanya peningkatan hasil belajar siswa dari pra siklus, siklus I hingga siklus II yaitu pada pra siklus diketahui hasil belajar kompetensi pengetahuan dari jumlah siswa 32 hanya ada $7(21,88 \%)$ siswa yang mendapatkan nilai $\geq 73$ (KKM) dengan nilai rata-rata kelas 55,88; pada siklus I sudah ada peningkatan menjadi 21 $(65,63 \%)$ peserta didik yang mencapai KKM dengan nilai rata-rata kelas 74,84 dan pada siklus II sudah ada 29 (90,63\%) peserta didik yang mendapatkan nilai mencapai KKM dengan nilai rata-rata kelas 82,38 . Peningkatan hasil belajar ini juga terdapat pada hasil belajar keterampilan atau kinerja dimana pada pra siklus hanya ada $9(28,13 \%)$ siswa yang mencapai KKM (73) dengan nilai rata-rata kelas 59,06; pada siklus I sudah ada $19(59,37 \%)$ peserta didik yang mendapatkan nilai mencapai KKM dengan nilai rata-rata kelas 75,59 dan siklus II sudah mencapai $32(100 \%)$ peserta didik yang mendapatkan nilai mencapai KKM dengan rata-rata kelas 80,06.

\section{DAFTAR PUSTAKA}

Al lamri, Ichas Hamid dan Tuti Istianti Ichas. 2006. Pengembangan Nilai Dalam Pembelajaran Pengetahuan Sosial Dasar. Jakarta: Departemen Pendidikan Nasional.

Aqib, Zainal. 2008. Penelitian Tindakan Kelas. Bandung: CV. Yarma Widya.

Arikunto, Suharsimi. 2010. Prosedur Penelitian Suatu pendekatan Praktek. Jakarta: Rineka Cipta.

Bafadal, Ibrahim. 2004. Manajemen Perlengkapan Sekolah Teori dan Aplikasinya. Jakarta: Bumi Aksara.

Chaplin, J.R. \& Messick, R.G. 1992. Elementary Social Studies: A Practical Guide. New York: Longman.

Djamarah, Bahri Syaiful dan Aswan Zain. 2006. Strategi Belajar Mengajar. Jakarta: Rineka Cipta.

Djodjo, S, dkk. 1992. Pendidikan llmu Pengetahuan Sosial. Jakarta: Depdikbud

Ibrahim, Muslimin. 2010. Pembelajaran Inkuiri, Jakarta: Rineka Cipta.

Kamdi, W dkk. 2007. Model-Model Pembelajaran Inovatif. Universitas Negeri Malang. Malang

Kunandar. 2007. Guru Profesional: Implementasi Kurikulum Tingkat Satuan Pendidikan (KTSP) dan Sukses dalam Sertifikasi Guru. Jakarta: Rajagrafindo Persada.

Mulyasa, E. 2007. Menjadi Guru Profesional menciptakan Pembelajaran Kreatif dan Menyenangkan, Bandung: Rosdakarya. 2008. Implementasi KTSP, Kemandirian Guru dan Kepala Sekolah, Jakarta: Bumi Aksara.

Nurhadi, dkk. 2004. Pembelajaran Kontekstual (Contextual Teaching And Learning/CTL) dan Penerapannya Dalam KBK. Malang: UM press

Peraturan Pemerintah Republik Indonesia Nomor 19 Tahun 2005 Tentang Standar Nasional Pendidikan, Presiden Republik Indonesia, tersedia di: https://kemenag.go.id/file/dokumen/PP1905.pdf 
Purwanto, Ngalim. 2007. Psikologi Pendidikan. Bandung: PT Remaja Rosdakarya.

Puskur. 2001. Kurikulum Berbasis Komperensi, Mata Pelajaran Sains Sekolah Dasar. Jakarta. Kompas

Rusman. 2012. Model-Model Pembelajaran, Bandung: Seri Manajemen Sekolah Bermutu.

Sagala, Syaiful. 2009. Kemampuan Guru dan Tenaga Kependidikan, Bandung: Alfabeta.

Samlawi, Fakih dan Bunyamin Maftuh. 1999. Konsep Dasar IPS. Departemen Pendidikan dan

Kebudayaan. Jakarta

Sapriya. 2009. Pendidikan IPS. Bandung: Rosda Karya.

Sudjana. 2001. Metode \& Teknik Pembelajaran Partisipatif. Bandung: Falah Production.

Sumantri, Numan. 2001. Pembaharuan Pendidikan IPS. Bandung: Rosda Karya.

Sutikno, Sobry. 2013. Belajar Dan Pembelajaran, Upaya Kreatif Dalam Mewujudkan Belajar dan Pembelajaran, Lombok: Holistica

Winataputra Udin S, dkk. 2007. Teori Belajar dan Pembelajaran. Jakarta: Universitas terbuka. 